\title{
Innovative Practice Teaching of Ornamental Plant Application Course System*
}

\author{
Min Liu \\ College of Arts and Sciences \\ Yunnan Normal University \\ Kunming, China
}

\begin{abstract}
In order to improve the teaching effect of ornamental botany, this paper analyzes the characteristics of design-related majors (landscape architecture, environmental art, urban and rural planning and architecture) and constructs the framework of ornamental plant application course through the innovative practice teaching. Through diversified practical teaching methods and efficient use of the advantages of the Yunnan region, the innovative curriculum assessment has been incorporated into the entire reform of the curriculum system. The results of the four-year research and practice show that the reform of the curriculum system of ornamental plants using innovative practices as the main teaching method has played a good role in improving students' ability to learn and use knowledge and expand the applicability of their employment areas; and based on this, a teaching mode with Yunnan characteristics is formed.
\end{abstract}

Keywords -ornamental plant application; curriculum system reform; practice teaching; design-related majors

\section{INTRODUCTION}

All major agriculture or forestry colleges and universities and some comprehensive universities in the country that have major in environmental design have plant-related courses at different levels, including specialized basic courses (botany, dendrology, and flower science) and design and application courses (garden plants Landscape design, flower application design), these courses are designed to further improve the relevant professional practice ability. How to implement the practicality of curricular construction of ornamental plant application, build a new form of applied university and promote the cultivation of talents are longstanding practical measures of design specialty (garden, environmental art, urban and rural planning and architecture) of Yunnan Normal University.

\section{INNOVATIVE PRACTICAL EDUCATION IS THE ONLY WAY TO TRAIN DESIGN PROFESSIONALS}

Practical application ability is the core value of designrelated majors. The practical education of the design majors of the College of Arts and Sciences mainly embodies in four

* This article is supported by "Research on the Reform of Curricula for Recognition and Application of Ornamental Plants in Design Specialty" (12SJZL04) of the research project of Teaching Reform of Higher Education in Yunnan Province parts: ornamental plant application module, design drawing module (including hand drawing and machine painting), project design module and engineering application module. As we all know, knowledge starts with practice; in recent years, we have learned from the survey on the training mode of relevant colleges and universities in Yunnan that innovative practical education in design specialty mostly focuses on new design concepts and methods, actual practice implementation of these majors is often fragmented and individualized while the design of professional modules of the practical application of the four modules are relatively independent and interdependent. Hereby, the College of Arts and Sciences intends to form a complete plant application knowledge module via constructing ornamental plant application module curricula, to implement practice teaching of ornamental plant application courses so as to promote the practicality and innovation of professionals' training, to help students pursue innovation in practice and put creative ideas into practice in conjunction with design courses to improve their own innovative ability of design majors, namely to cultivate innovative ability in innovative practice, to highlight the green engineering professionals training mode and to explore innovative talents cultivation methods.

\section{ORNAMENTAL PlANT APPLICATION COURSE SYSTEM CONSTRUCTION}

\section{A. Innovative Ornamental Plant Curriculum Framework}

Ornamental application curriculum system framework determines the professionalism of the curriculum; multidisciplinary cross promotes the breadth of the curriculum system. Ornamental botany courses in different majors should not only pay attention to the design of common requirements, but also consider the differences of different majors in the same course. It is conducive to the development of students' personalities, which helps to enhance the overall improvement of students' professional knowledge learning, and helps students to conduct their design from the perspective of sustainable development, the professional practice teaching hours are accounted for more than $40 \%$ to all design-related majors and reached over $67 \%$ to architecture.

Ornamental plant application course system is the core backbone of landscape architecture, basic teaching content 
should be designed to increase the learning of basic knowledge, the scope of plant identification should be widened, teaching hours should be relatively long, students should have the ability to identify plants independently from the field via the training, and should form thick-based plants Identify foundation through the courses, the application of teaching part would give the students a comprehensive training from planning to specific programs and practical methods of application. Environmental Art major highlights the woody, herbaceous plants with higher appreciation value, pay more attention to plant landscape design. Urban and rural planning major emphasizes woody plants and focuses on plant planning and design from the planning point of view. The architecture aims at deepening the students' understanding of the interdisciplinary subject so that they can further grasp the opportunity of ecological construction and understand the connotation of ecological civilization development in the course of their work, the teaching contents and practice venues should emphasize the common landscape trees, bushes and grass around buildings with typical landscape views so as to understand the composition of plants in the construction of the landscape form. According to the different characteristics of the students and the different stages of development of the disciplines, the teaching frameworks of the above majors should be designed to provide individualized innovative practice platforms and development space for students of different majors because of the design and planning of causal factors.

\section{B. Characteristics of Innovative Practice of Ornamental Plant Application Course System}

The construction of the ornamental plant application course system is not a simple combination of courses. In particular, the innovative practice teaching is based on the full analysis of the teaching contents, teaching methods and practical teaching requirements of different majors, so as to optimize teaching contents and integrate teaching resources, give full play to the geographical advantages of Yunnan's plants in all four years of university study, let the students understand the plants in different representative areas of Yunnan through the complex three-dimensional climate in Yunnan, and construct a broad professional perspective, lay a solid foundation for future career development, in the meantime, form the distinctive teaching system.

\section{The StRategy OF INNOVATIVE PRACTICE TEACHING IN ORNAMENTAL PLANT APPLICATION COURSE SYSTEM}

The innovative practice teaching of ornamental plant application course system does not only mean the innovation of teaching contents, but also emphasizes the cultivation of students' innovative awareness and ability. Through carrying out innovative practical education, we not only cultivate students' thick-based plant identification ability, but also cultivate their ability of asking questions in practice, carrying out research-oriented study based on actual problems, and of being able to understand the importance of ornamental plants towards professional development, to realize the problems existed and explore how to solve the problem, from which to establish professional self-confidence, foster innovation sprit and enhance innovation ability.

\section{A. To Promote Innovative Practices via Diversified Practical Teaching Methods}

Cultivating students' innovation consciousness and ability starting from the reform of practical teaching methods, analyzing teaching content, emphasizing two-way symmetry practice teaching, highlighting students' initiative awareness, combining teaching content and subject characteristics, using on-site teaching method, migrating teaching method, electronic information teaching methods and other teaching methods.

The on-site teaching method is the main practical teaching method used in plant-related basic courses, such as on-site teaching and verification teaching of ornamental plant identification, morphological terminology and plant taxonomy, and is a live lecture on the relevant chapter and section knowledge of basic knowledge, the key is to fully use the on-site plants (that is, physical teaching aids). The on-site teaching or verification of these intuitive knowledge points is especially significant for the students majoring in urban and rural planning and architecture with weak botany foundation. Students are usually deeply impressed by this kind of teaching method.

Plant landscape design, urban green space system planning courses or comprehensive plant practices should pay attention to its practical application in the design and engineering of gardens, landscapes, urban planning and architecture, and involve plant design, plant culture, plant cultivation, plant conservation management and other practical applications of knowledge, the specific application of the above mentioned knowledge is also a specific teaching case. Therefore, the teaching can be combined with the case analysis teaching method and with the peer teaching method, students in groups form, go deep into all types of parks, squares, residential and other sites, teachers guide students in observation, lead them to ask questions, analyze problems, solve problems, evaluate landscape plants and landscape projects. For example, measuring the morphological parameters of various trees at the project site, drawing plant configuration maps, examining the growth of plants, analyzing and evaluating the landscape design elements, etc.; from survey reports on scenes which have been completed through mutual discussions and comments with classmates and teachers, in order to enable students to acquire the comprehensive application of knowledge related capabilities: such as the ground cover plants and colored leaves plants in Kunming, fruit plants in central Yunnan, tropical city plant landscape and road trees in Xishuangbanna, landscape and specialized garden of Xishuangbanna Botanical Garden of Chinese Academy of Sciences, A combination of the Dali, Lijiang minority areas' landscape plants and architectural features. These form of innovative practice teaching mode.

In addition, teachers can give play to the teaching effects of modern electronic information teaching methods by guiding students to use modern electronic information acquisition and analysis methods such as scene 
photographing, image processing and image data collection, using the WeChat public account and QQ chat group, Achieve "freewheeling" between teachers and students and students at any time, with the exchange of information, access to ornamental plants related knowledge "cognitive reproduction" and other teaching results.

\section{B. To Promote Innovative Practices by Using Regional Advantages Efficiently}

In addition to indoor ornamental plants, colleges and universities in different regions will be restricted by different degrees of plant regionalization. Colleges and universities also use field plants in limited areas for on-the-spot practical teaching or in connection with fresh plants experimental teaching [2 9], apparently, this regional restrictions on the practice of teaching content and scope have, in varying degrees, caused the insufficiency of employment and comprehensiveness of the ornamental plant knowledge and ability of the relevant professional students.

The diversity of plants formed under different geographical locations and climatic conditions in Yunnan provides a practical teaching site that represents different regional characteristics for the field practical teaching of ornamental plants. Based on the typical monsoon climate characteristics in Dali and Lijiang, the practice of collecting temperate ornamental plants is carried out. Based on the climatic characteristics of the tropical monsoon forest in Xishuangbanna, the understanding practice of tropical ornamental plants is carried out, which includes the understanding of the growth habits of tropical plants. By using the subtropical monsoon climate characteristics in Kunming, in the wild or Kunming Botanical Garden, 99 Kunming World Horticultural Exposition Park, Kunming Top Ten Parks and other places to carry out subtropical plant species identification and application of practical teaching, in addition, the climate characteristics of Kunming are unique, they are expressed as "like spring all year around but the sunlight is quite hard in summer, becomes autumn in cloudy days and enters into winter immediately while rains", this provides the necessary climatic conditions for seasonal changes of plant landscape. The camellia of Golden Temple, the oriental cheery of Yuantong Zoo in spring, the lotus flowers of Daguan park in summer, the maple leaves of Botanical Garden, the gingko leaves of Yunnan University in autumn, the ancient plum of Heilongtan park in winter etc., are fully confirmed the characteristics of plant seasonal landscape in the environment, where vivid examples of plants can be touched and the intuitive experience of the seasonal phase of the landscape can be directly felt, understanding of these characteristics of plants, learning plant season landscape design methods, points become automatically much easier; in Stone forest world natural heritage area, we can understand limestone area plants. In addition to on-site practical teaching, you can also collect a variety of fresh plant specimens in the above-mentioned areas for the experimental teaching in the school. In this way, students can get knowledge of ornamental plants in different regions and geographically diverse climates in Yunnan.

\section{Flexible Curriculum Assessment Methods to Promote Innovative Practice}

A single final closed-book examination cannot fully test the students learning process and learning outcomes. On the basis of fully analyzing the professional background and students' learning situation of different majors, the targeted design and assessment methods are designed to promote the information transfer between teachers and students. Diversified content and form of assessment, such as the production of plant specimens, field practice photos taken to establish information base, to write the survey report and course essay, plant phenology monitoring assessment, afterschool reading garden literature and writing book report; case analysis and design, project discussion reports, PPT presentations, research papers, etc., can further validate the previous study, at the same time can help students plug gaps, but also to promote teachers' teaching and learning, to help teachers and students to establish a broad professional perspective for students in other courses Cross-use to lay a solid foundation.

The latter part of the comprehensive study of the students, not only can test the basic knowledge of the previous learning situation, but also to provide students with a broad space for thinking, to promote the creative practice of different majors.

\section{The IMPACT ON PROFESSIONAL TRAINING ModE FROM INNOVATION OF ORNAMENTAL PLANT APPLICATION COURSES}

\section{A. To Improve Professional Practice Ability}

Making full use of regional advantages in Yunnan Province through innovative practice teaching has effectively improved the teaching effect of the ornamental plant curriculum system. With various forms of on-the-spot practice teaching, students' learning interest and learning initiative can be stimulated to the greatest extent, the dull and boring teaching methods become vivid and interesting. The students become more active and willing to learn and explore instead of being forced to learn. They will try to explore in different ways and use their knowledge more comprehensively, thus, the ideal teaching effect is obtained. This effect is more reflected in the improvement of students' ability to acquire and use knowledge.

\section{B. To Promote the Innovation of Practice through the Promotion of Cross-integration between Multi- disciplines and to Build a Green Engineering Discipline}

According to the characteristics of different majors, we have developed professional teaching plans with professional pertinence for each specialty, which are clearly applicable to the field teaching, experimental teaching and internship contents, the number of class hours, the location and teaching requirements of on-site teaching and internship teaching, which also involves the combination of professional internships with various professions. Through four years of teaching practice, taking the construction of provincial-level "garden" specialties as a driving force to 
promote the professional development of urban and rural planning and construction, highlighting the concept of green and sustainable development, our team took the lead in constructing a special teaching system of ornamental plants for design specialty in Yunnan province, forming a characteristic training mode with combination of ecological and green engineering.

\section{To Enhance the Idea of Design Engineers to Enhance Employment Adaptation}

On-site case teaching and on-site comprehensive inspection teaching can especially cultivate the students' "internship engineers" ideas and basic abilities. Taking students as internship engineers or letting them play the role of an internship engineer, or allowing them to independently make a comprehensive analysis and evaluation on on-site engineering cases, and even make the analog design or improved design, can actually induce or stimulate students' desire to become an "internship engineer" and put into practice, through the use of knowledge, and the comparison of facts, idea exchange between students, and discussion with on-site engineers and technical personnel, guidance and recognition from teachers to cultivate students' "internship engineer" basic ability or even employability. At the same time, the extensive knowledge of ornamental plants obtained under plant diversity and real-time conditions in Yunnan has laid a more extensive knowledge base for students' employment in different regions, thus improving the adaptability of employment in different regions for students.

\section{CONCLUSION}

The construction of ornamental plant curriculum system is an important measure of innovation in practical teaching of Gardens, Horticulture, Environmental Arts, Urban and Rural Planning and Architecture of College of Arts and Sciences, as well as an important foundation for students' professional knowledge and professional working ability. Therefore, in order to improve the teaching Quality of above mentioned majors, in the actual teaching work, relying on the unique advantages of Yunnan's plant diversity, dedicated to the teaching practice and exploration of ornamental botany, our team takes the lead in Yunnan Province to reform the ornamental plant application courses within colleges and universities where have design related majors. Over the past four years, more than 3,000 students of different majors engaged in ornamental plant teaching practice and the results show that indeed can effectively enhance students' practical ability. The promotion is not only about answers with flexibility and comprehensiveness in the examinations, but also more about the improvement of students' autonomous learning ability, the comprehensive application of innovative practical ornamental plant-related knowledge in graduation project and graduation thesis, thus improving cultivation quality of application-oriented undergraduate talents.

\section{REFERENCES}

[1] Lianfang Yao. Teaching Methods for Landscape Architecture [M].Beijing: Higher Education Press, 2012.

[2] Hu Guofu, Hu Baozhong, Chang Ying, Li Fenglan. Teaching Reform and Practice of Fieldwork in Teaching Botany[J]. Journal of Northeast Agricultural University (Social Science Edition), 2009, 7(1):30 32.

[3] Lu Jianguo, Gu Yachun etc. Innovation and Practice within Heuristic Teaching: Based on Teaching Cases of "Ornamental Botany" [J].Forestry Education in China,2011,29(6):67 69.

[4] Qiang Sheng. How to Build National Level Excellent Resource Sharing Course of Botany: Ideas and Actions [J]. China University Teaching, 2013(8):32 37.

[5] Ji Hua,Chen Longqing etc. Discussion on Reform of Lanscape Dendrology Course from The Angle of Cognition [J].Forestry Education in Chin, 2010(9):59 61.

[6] Qin xinsheng. How to Improve the Studentes' Ability of Plant Identification in Agricultural and Forestry Universities [J].Time Education,2009(1):90 91.

[7] Liu Xiuli. Exploration on Practical Teaching Methods of "Landscape Dendrology" [J]. Forestry Education in Chin, 2013(1):52 55.

[8] Yu Xiaonan, Zhang Qixiang. Exploration on Reform for Practical Teaching of "Landscape Dendrology"" [J]. Forestry Education in Chin, 2010(3):62 64.

[9] FENG Fu-juan, TAO Lei, MU etc. The Practice and Effect of Innovative Teaching on Botany Fieldwork [J]. Research and Exploration in Laboratory, 2014,33(7):198 200.

[10] Zhao Hong, Han Xiao-di. The Construction of 3D Teaching Model of Botany Field Practice [J]. Research and Exploration in Laboratory,2007,26(4):129-131.

[11] Li Xinhua, Cases Analysis of Field Practical Teaching of Botany in a German University and Its implications [J]. Research and Exploration in Laboratory,2013,32(4): 176-180.

[12] Gu Binglin, Wang Dazhong etc. The Innovative and Practical Education - - A Way of Training Creative Talents Based on Building High- Level Academic Disciplines [J].Tsinghua Journal of Education, 2010(2):1 5. 